\title{
Data and Progress in Peace and Conflict Research·
}

\author{
Kristian Skrede Gleditsch \\ University of Essex \& \\ Peace Research Institute Oslo (PRIO) \\ Nils W. Metternich \\ University College London \\ Andrea Ruggeri \\ University of Amsterdam
}

- The authors are listed alphabetically, equal authorship implied. Gleditsch is grateful for support from the Research Council of Norway (213535/F10 \& 180441/V10) and the European Research Council (313373). We thank Nils Petter Gleditsch, Ron Smith, and Henrik Urdal for helpful discussions and comments. Draft version: Do not cite. 


\begin{abstract}
We highlight how efforts to collect systematic data on conflict have helped foster progress in peace and conflict research. The Journal of Peace Research has played a key role in these developments, and has become a leading outlet for the new wave of disaggregated conflict data. We survey progress in the development of conflict data and how this interacts with theory development and progress in research, drawing specifically on examples from the move towards a greater focus on disaggregation and agency in conflict research. We focus on disaggregation in three specific dimensions, namely the resolution of conflict data, agency in conflict data, as well as the specific strategies used in conflict, and we also discuss new efforts to study conflict processes beyond the use of violence. We look ahead to new challenges in conflict research and how data developments and the emergence of 'big data' push us to think harder about types of conflict, agency, as well as the 'right' level of aggregation for querying data and evaluating specific theories.
\end{abstract}


'War, to be abolished, must be understood. To be understood, it must be studied' (Deutsch, 1970: 473).

'A theory that ignores existing evidence is an oxymoron ... and such an oxymoron should not be called a theory' (Lieberson, 1992: 4).

\section{Introduction}

The founding of the Peace Research Institute Oslo (PRIO) is very much associated with the behavioral revolution in the social sciences. The aspiration to study conflict and peace in a scientific manner, using formally stated arguments and systematic empirical analysis, has remained central to the Journal of Peace Research (JPR) over its first 50 years. Systematic data development efforts have been crucial for rigorous empirical analysis of theories of conflict of peace, and the Journal of Peace Research (JPR) has played a prominent role in fostering and disseminating data.

In this article, we wish to highlight how data development efforts help advance research on conflict and peace. Data resources can obviously be of direct use to evaluate existing theoretical arguments. Less appreciated is the important role that data development efforts often play in spurring further theory development and a greater awareness of issues in research, and thus in turn fostering progress in conflict research. Our brief survey of the development of conflict data and applications of these in research highlights the interaction with theory development. Rather than adopting a strict chronological narrative or aiming to be 
comprehensive, we use the movement towards more disaggregated approaches to conflict data to structure and organize our review. We focus first on disaggregation in three specific areas or domains, namely the resolution of conflict data, agency in conflict data, as well as the specific strategies used in conflict. We then turn to new efforts to study conflict beyond the use of violence. We document how progress in conflict and peace research arises as working with data forces us to think harder about types of conflict, agency, and the 'right' level of aggregation in relation to specific theories.

Given the wide range of data sources on conflict our review cannot aspire to be exhaustive, and our focus is primarily focused on comparative studies of war and conflict. We acknowledge up front that we do not cover a wide range of conflict data sources as well as important forms of new efforts to develop more disaggregated information on features believed to influence the risk of violent conflict such as social and economic factors or political institutions. Moreover, we are unable to give due attention to the many studies using detailed data on conflict events within individual countries ${ }^{1}$ or survey research on individual participants in conflict or the effects of conflict. ${ }^{2}$ Despite the limitations in our focus and scope, however, we

${ }^{1}$ See, for example, Balcells (2011), comparing pre-war political support and the use of direct and indirect violence in municipalities in Spain, Lyall (2011), using data on the ethnic composition on soldiers in counterinsurgency operations in Chechnya and their effect on subsequent violence, and Weidmann (2011) relating the ethnic makeup of specific districts to variation in violence in the Bosnian civil war.

${ }^{2}$ See, for example, Blattman (2009) for interviews on conflict participation and subsequent political activism, and various studies presenting individual level survey data from conflict countries in the JPR special issue edited by Verwimp, Justino \& Brück (2009). 
believe that our review and examples help illustrate more general trends in the interaction between data and theory development and their synergetic role in scientific progress.

\section{A brief history of conflict data and the role of JPR}

We start by a brief survey of modern efforts to collect systematic data on conflict and peace and the specific role that JPR has played in conflict data development since its inception. The best known early major effort to gather data on conflict and violence is undoubtedly the work of Richardson (1960a), who in the 1930s gathered data on 'deadly quarrels' and their severity, and conducted a series of important pioneering studies on conflict (see, e.g., Richardson, 1948). Richardson's data and other pioneering data collection efforts such as Sorokin (1957) and Wright (1942/1965) were used as sources for compiling the Correlates of War (COW) project's first list of wars. The COW project later extended coverage to the modern era and proposed an influential definition of 'war' as periods with sustained fighting generating more than 1000 battledeaths (see Singer \& Small, 1972; Small \& Singer, 1982).

Early data development efforts were typically described in books, but journal articles have become increasingly important outlets for presenting data. JPR has played a key role here, although we also recognize the important contributions made by other journals such as Conflict Management and Peace Science and International Interactions. Beginning with Wallensteen and Axell (1993), JPR has published an annual update on the Uppsala Armed Conflict Data. These data use a substantially lower annual battledeath threshold $(25+)$ to identify violent conflicts than the COW data, and thus allow studying a larger number of violent events. Gleditsch et al. (2002) 
presented an extension of the original post-1989 database back to $1945 .^{3}$ The Armed Conflict Data have become very influential in stimulating the new wave of empirical research on civil war (see, e.g., Blattman and Miguel, 2010). They have also formed the point of departure for many new data projects, identifying features such as violence against civilians in civil war (Eck and Hultman, 2007), conflict termination in civil wars (Kreutz, 2010), or mediation in civil wars (DeRouen et al., 2011), all described in JPR articles.

The popularity and prominence of many of the data articles published in JPR is clear when looking at citations. Jaggers \& Gurr (1995), introducing the POLITY III data on democracy, is by far the most cited article in the journal, with 563 citations in Thomson Reuters Web of Knowledge as of May 2013. This is closely followed by Gleditsch et al. (2002) on the Uppsala/PRIO Armed Conflict Data, with 481 citations. Indeed, as many as 4 of the 10 most cited articles in JPR since its inception are data articles, attesting to how data articles tend to be

\footnotetext{
${ }^{3}$ Most current conflict research tends to focus on the period after World War II, due in part to the scarcity of sufficiently detailed data on other relevant features such as macroeconomic data prior to 1945 , as well as possible concerns over the problems in comparisons across very different historical periods with dramatically different technologies and levels of development. Still, many conflict data sources extend much further back in time. The COW data extend to the Congress of Vienna (1816), while Levy's (1983) data on great power wars go back to 1495, and Brecke's (1999/2012) Conflict Catalogue list conflicts satisfying Richardson's criteria back to 1400. A number of recent books examine long-term trends in conflict and violence, including Gat (2008), Payne (2004), and Pinker (2011), informed by these data sources.
} 
widely used and hence widely cited. ${ }^{4}$ Assessing the number of data articles that have been published in JPR raises some difficult demarcation issues. Many articles that introduce new data sources are often focused around a specific research questions rather than the data. More problematically, articles often do not provide much detail on the data themselves. JPR has moved towards streamlining a specific format for articles presenting new data called Special Data Features (SDFs). This is a relatively recent development, appearing first in 2000. Still, by our (conservative) count, $36 \mathrm{SDF}$ have been published in JPR in the first 12 years of the format. Figure 1 indicates a trend towards more SDFs per year, with a notable increase since 2005.

\footnotetext{
${ }^{4}$ Gibler and Sarkees (2004), presenting the new Correlates of War alliance data, has been cited 134 times as of May 2013, while there are 128 citations to Vanhanen (2000), describing a new data set to measure democracy based on election results.
} 


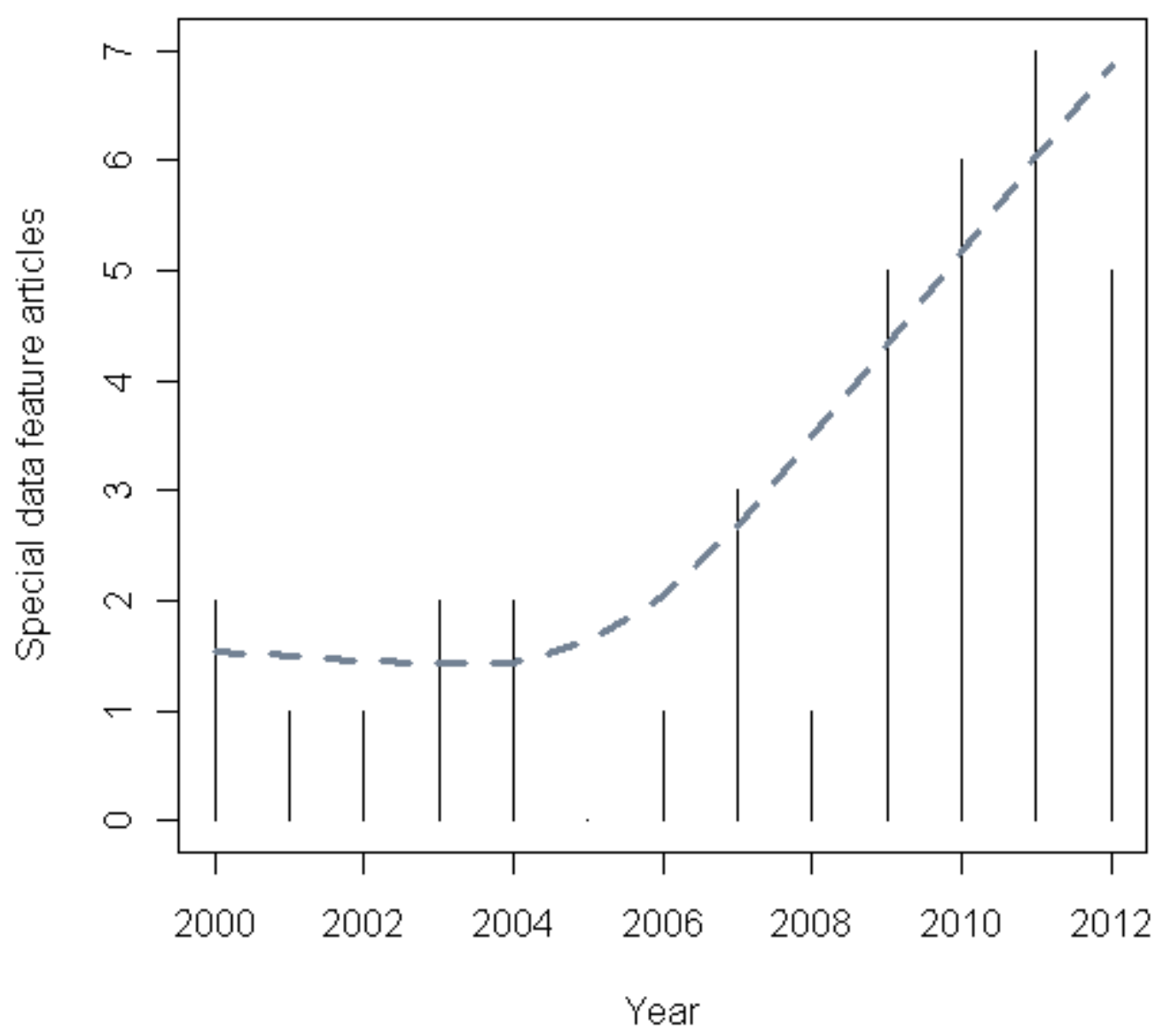

Figure 1: Number of Special Data Features published in the Journal of Peace Research per year (black bars), with a local regression (LOWESS) trend superimposed (dashed grey line).

Having reviewed some initial figures on the growing supply of and demand for conflict data, we now turn to substantiate our broader claim that the development of new data have interacted with theory development and progress, focusing on the trend towards greater disaggregation in the three dimensions discussed above. 


\section{Disaggregation I: The resolution of conflict data}

Most traditional efforts to collect data on conflict have been content to simply report a list of wars, with their start and end dates, and participating or affected countries. Adding greater detail and resolution can often be helpful to represent or understand the underlying causes and dynamics of wars. Aiming to explain and predict the occurrence, escalation, duration, termination, and possible spread of 'deadly quarrels', the pioneering efforts of Richardson (1960a) suggested a number of different ways of displaying information on wars, including for example (1) geocoding wars by location or mapping them, (2) a matrix representation of belligerent dyads, or analysis of relations between pairs of actors, (3) a sequential representations of war, as well as (4) to rank wars by their importance or severity. Richardson's approach in many ways anticipated common units and approaches in the contemporary study of conflict.

Most of the early research on conflict was highly aggregated, and used the wars themselves or episodes of violence as the unit of analysis, without explicit comparisons to "nonevents' or periods without wars. Such analyses may of course provide helpful descriptive material on wars and their characteristics. However, looking at wars only also raises the now better recognized problems of 'selection on the dependent variable', and does not allow making comparisons to periods without conflicts or actually examine differences between conflict events and other periods (see King, Keohane \& Verba, 1994). In addition, early research primarily examined the relationship between characteristics of international systems and the incidence of conflict. Singer, Bremer \& Stuckey (1972), for example, examined whether wars were more or less frequent in international systems with specific properties, such as a high power 
concentration or a larger number of states with more balanced capabilities, based on a measure of power concentration computed for particular time periods. Their results suggested large differences between the $19^{\text {th }}$ and the $20^{\text {th }}$ century. They surmised that changes in the nature of diplomacy might account for the difference, although they did not actually have data that would allow them to examine these arguments empirically.

The focus on the system level may have seemed natural given its salience in traditional international relations theory (see, e.g., Singer, 1980). In retrospect, however, it is hardly controversial to concede that the highly aggregated systemic analyses of war largely failed to deliver on the promise of creating a cumulative science of conflict and peace. In part due to the dissatisfaction with the meager findings from system-level research, many researchers started comparing wars and no-conflict episodes at the level of either individual countries or dyads, i.e., pairs of countries. This approach also helped bring empirical analyses closer to behavioral theories of conflict, which often tend to stress the characteristics of the states participating in conflict, or the interaction between actors over some incompatibility, as in Richardson's (1960b) famous arms race model (see also Boulding, 1963). Analyzing data on conflict or its absence by country or dyad period has helped promote a more systemic approach to comparative conflict research, and facilitates integration with other data sources collected annually for countries or relations between states such as GDP per capita or trade flows. Country-years and dyad-years became prominent in early studies of the relationship between internal and external conflict, which in turn set the stage for the subsequent research linking political regime type and conflict through the so-called dyadic democratic peace (see Oneal et al., 1996; Rummel, 1985; Wilkenfeld, 1968). Country and dyad-years have now become the dominant approach to collecting or analyzing data on conflict. Moreover, the dyadic research design used to study 
militarized disputes between states have influenced more recent efforts to study civil war from a dyadic perspective (see, e.g., Cunningham et al., 2009; Harbom et al., 2012).

The turn away from the systemic level was also accompanied by broader scope in the study of interstate conflict beyond the largest and most destructive wars. Full-fledged interstate wars are relatively rare events, and there are many serious crises between states that could give rise to war such as the Cuban Missile Crisis that for various reasons do not escalate. Many researchers have argued that studying such 'near misses' and lower-level conflictual incidents more systematically may help us get a better handle on the factors that make escalation to war more likely as well as the possible conditions that may prevent violence. The Interstate Crisis Behavior data project, first envisioned in 1975, has sought to systematically identify crises, defined as 'a situation ... which gives rise to decision makers' perceptions of threat to basic values, finite time for response, and the likelihood of involvement in military hostilities' (see Brecher \&Wilkenfeld, 1982: 383). These data have facilitated a large body of research looking at escalation in crisis, based on features such as characteristics of the actors and conflict management techniques. A similar development to identify conflict short of war was also developed in the COW project through the Militarized Interstate Dispute (MID) data (see e.g., Gochman \& Maoz, 1984; Goshen, Palmer \& Bremer, 2004; Jones, Bremer \& Singer, 1996). Jones et al. (1996: 163) define militarized interstate disputes as '...united historical cases of conflict in which the threat, display or use of military force short of war by one member state is explicitly directed towards the government, official representatives, official forces, property, or territory of another state'. The definition makes it clear that the MID data supplement the COW data on wars with cases that possibly could have led to war, even if we ultimately do not observe escalation or any battledeaths (unlike other lower level conflict data that remain strictly death 
based, such as the UCDP data). The MID data have become a widely used resource, and indeed most recent research on dyadic interstate conflict tends to look at MIDs rather than wars. Whereas wars are rare events, MIDs are much less frequent, and many researchers examine the latter as a more comprehensive evidence base for insights on the causes and consequences of war. $^{5}$

The near exclusive emphasis on systemic international relations theory also led to a relative neglect of the COW project's data on civil wars. These were often regarded as less important and simply reflecting systemic features, as for example in the popular notion of socalled proxy wars, where superpowers supported opposite sides in civil wars (see Salehyan 2010). The need to analyze civil conflicts at levels of escalation below 'war' or 1,000 deaths became apparent with the increasing number of smaller intra-state conflicts in the early 1990s. Many have highlighted the need to distinguish between the specific incompatibilities of civil wars, as some countries may experience multiple conflicts at the same time over distinct

${ }^{5}$ Many researchers simply characterize disputes as 'war' and assume that the correlates of wars and MIDs are essentially the same (e.g., Harrison \& Wolf, 2012), but others question whether this is warranted (e.g., Gleditsch \& Pickering, forthcoming). For example, 'use of force', the second most severe category of the MID data, includes events such as fishing disputes or seizures by coast guards that may not include any direct involvement by state leaders, and only $20 \%$ of all instances of use of force in the data entail any recorded deaths. Moreover, it is questionable whether that available information is sufficient to systematically identify such lower level events the further back one goes in time. This may be less of an issue for studies comparing dyadic profiles, but such potential selection problems can make global trend analyses based on the MID data problematic. 
incompatibilities that may have completely different attributes (e.g., the separatist conflicts in Assam and Kashmir in India). Finally, the increase in internationalized post-Cold War civil conflicts did not sit well with the COW project's mutually exclusive typology, where wars must be either international or intrastate. ${ }^{6}$ Many researchers have examined linkages between intra and interstate conflict, and for example found strong evidence that ongoing civil wars often generate militarized conflict between states (Gleditsch et al., 2008; Salehyan 2009).

Some scholars have pointed to the limitations of looking at wars as larger episodes. Many data sources identify 'wars' by battledeaths exceeding some threshold over a period (typically a year), which 'break out' at some date $t$ and then last until a later date $t+k$, given some criteria for ongoing activity. Aggregate spell data of this type provide no information on conflict dynamics or events within conflicts over time. Beginning with the game-theoretic revolution in the study of conflict in the 1970s, researchers often postulated propositions about conflict as processes where the specific patterns of interaction between parties determine whether or not initial disputes escalate to war (see, e.g., Bennett \& Stam, 2003; Morrow, 2000). This often led to an increasingly notable disjuncture between theories of conflict that are ever more specific in highlighting micro-mechanisms and data at a relatively high level of aggregation.

\footnotetext{
${ }^{6}$ For example, Vietnam 'ceases' to be a civil war in the COW project as it is deemed international with the increased US involvement in 1965. The COW project has reclassified conflicts in different releases - for example, the Nagorno-Karabakh conflict was previously considered interstate, but is now classified as a civil war in Azerbaijan (see Gleditsch, 2004 for additional discussion). In our view, a better alternative is to focus on inter-state and intra-state action in conflicts, without trying to impose a single overall 'type'.
} 
As such, many researchers have become interested in less aggregated data on conflict processes and turned to event data that may allow studying interaction by arranging specific actions as temporal sequences. Some early contributions detailed sequences of interactions in specific events such as World War I (see, e.g., Pool, 1965), but the earliest systematic global event data development efforts are Azar's (1980) Conflict and Peace Data Bank (COPDAB) and McClelland's (1983) World Event/Interaction Survey (WEIS) project. McGowan et al. (1988) noted that event data had become the second most common form of data by the late 1980s. Traditional projects tended to rely on undergraduate student coders, but advances in computing have made automated coding directly from electronic sources possible, with the Kansas Event Data System (KEDS) and the VRA-Reader as prominent examples of the available software technology. King \& Lowe (2003) examine possible advantages of machine coding over human coders, who may be prone to systematic biases in coding specific events. New event data projects have also fostered the development of new dictionaries for a winder rage of actors and events. Examples here the Integrated Data for Events Analysis (IDEA, see Bond et al., 2003), encompassing a typology of events including non-violent direct action, and the Conflict and Mediation Event Observations (CAMEO) framework (Gerner, Schrodt \& Yilmaz, 2009), intended to facilitate the study of conflict management techniques. The new Global Data on Events, Location and Tone (GDELT) identify over 200 million cooperative events over the period 1979-2012 through parsing electronic newsfeeds and archives (see Leetaru \& Schrodt, 2013).

There is also increasing attention to the spatial location and characteristics of conflict. Many conflict data have traditionally had little to say about where conflicts take place, and merely report that country A is involved in, or experience conflict, over some time period. 
Buhaug \& Gates (2002) and others have noted that civil wars rarely engulf entire countries, but often take place in confined and atypical areas, leaving much of the country at relative peace (see also Buhaug \& Lujala, 2005). As such, it is essential to consider the local context of conflict. Many researchers have started to code additional geographic information on conflict in a Geographic Information Systems (GIS) format. This line of research has suggested that civil war consists of two important sub-types, namely conflicts that take place in the periphery - which are often persistent, remain at low intensity, and defy a clear military outcome - and civil wars in the capital city, typically arising from coup attempts (which may become violent conflicts if they generate sufficient deaths) and normally with relatively short duration as one side tends to quickly gain the upper hand. Moreover, there is an important distinction between states fighting on their own territory and states fighting elsewhere in the world, possibly against other actors that may not be able to target the state's core territory (see Braithwaite, 2010; Gleditsch, 2002). An early example of event data with spatial information in JPR is the Colombian conflict database developed by Restrepo, Spagat \& Vargas (2006). More recently, JPR has published comprehensive spatial data on the location of militarized interstate disputes (Braithwaite, 2010), the so-called Armed Conflict Location and Event Dataset, which identifies events within civil wars (Raleigh et al., 2010), and the Conflict Sites polygon data indicating location and extent of UCDP civil conflicts (see Hallberg, 2012).

\section{Disaggregation II: Agency in conflict research}

So far we have discussed disaggregation in conflict data primarily in terms of resolution and detail in the records (i.e., 'when' and 'where'). However, disaggregation in conflict research also 
accompanies a renewed focus on understanding agency in conflict studies. Indeed, the choice of the analytical unit normally assumes a certain theoretical underpinning of the actors highlighted. Early studies at the system level often tended to see war as something inherent and inevitable in anarchic international systems, and thus often deemphasized agency as the specific actors in conflicts presumably would be irrelevant and interchangeable. Traditional realist concepts such as 'national interest' suggest that countries have largely invariant and exogenously defined interests, and make it natural to talk about specific countries going to war rather than their individual leaders.

Some approaches routed in psychology have always emphasized how individual leader differences can influence foreign policy decisionmaking (see, e.g., Hermann 1977, 1980). However, the specific decisionmakers received only limited attention in general research on conflict until the emergence of research on the so-called democratic peace. Interest now turned to how domestic political institutions could structure the incentives of decisionmakers, as well as how accountability to domestic audiences might make leaders reach decisions they otherwise would not make (e.g., Fearon 1994; Schultz 1999). One line of research has highlighted the importance of regime types beyond the autocracy-democracy dichotomy, as different autocratic regimes have different incentives and constraints on the use of force and violence (see, e.g., Fjelde, 2010; Weeks, 2012). Other researchers examine individual leaders and how their risk of losing office affects the use force, possibly for diversionary purposes, as well as the likelihood that other states will escalate conflicts with leaders given their relative security of office (e.g., Chiozza \& Goemans, 2003, 2004). Archigos, a database on political leaders published in JPR, has become a much used resource (see Goemans et al. 2009). 
In civil war studies we see a parallel development towards greater focus on actors (see e.g., Cederman \& Gleditsch, 2009; Metternich et al., 2013). Early studies tended to treat civil war as something that 'happened' in specific countries, with little interest in who may engage in conflict and their plausible motivation for doing so. Indeed, some contributions have argued that civil wars may be inevitable in week states or will occur whenever feasible (see, e.g., Collier, Hoeffler \& Rohner, 2009; Fearon \& Laitin, 2003). However, individual countries may experience several unrelated organizations in conflict with the state, with entirely different motivations. For example, the UCDP data code no fewer than 8 organizations involved in civil conflicts in India in 1997, with one aiming to overthrow the government (i.e., the Marxist organization the People's War Group) and the other 7 organizations aiming for autonomy or secession for distinct territories (i.e., Assam, Bodoland, Kashmir, Kukiland, Manipur, Nagaland, and Tripura). Many studies of civil war at the country level emphasize state weakness or lootable resources as risk factors, de-emphasizing the non-state actors and their possible political motivations and grievances. The fact that different organizations may have different motivations highlights the need for a shift from monadic, country-focused studies of conflict to a dyadic approach, emphasizing how specific non-state actors interact with the central government in ways that may lead to violence, or not (see Cederman \& Gleditsch, 2009; Cunningham, Gleditsch \& Salehyan, 2009; Harbom, Melander \& Wallensteen, 2008).

Dyadic analyses have long been common in studies of interstate conflicts, but efforts to study the onset of civil war in a dyadic approach raise a series of problematic issues. The population of states as potential actors is reasonably well defined, and it is at least in principle easy to generate a population of dyads that may engage in interstate conflict. It is much more difficult to identify potential insurgent groups in advance of the outbreak of civil conflict. 
Although analyses of actors in civil wars can provide important insights about conflict processes, we again face the old problem of selection on the dependent variable without an explicit comparison to cases without civil war.

One approach to looking at potential actors in civil war focuses on ethnic groups. Civil wars are often fought along ethnic lines and over particular claims for autonomy or secession. It thus seems plausible that indicators of group motivations and opportunities for political action should help understand when we are likely to see resort to violence. The so-called Minorities at Risk (MAR) project developed by Gurr (1993) has collected systematic empirical data on political and economic group characteristics and helped foster a new generation of studies of ethnic conflict after the Cold War.

The MAR data have been criticized for only considering minorities and the possible biases that may arise from focusing too much on discriminated minorities at the expense of majorities or groups not at risk. Inspired by theories of nationalism and Wimmer's (2002) emphasis on the political nature of ethnicity in terms of access to state power, the so-called Ethnic Power Relations (EPR) project has assembled a more comprehensive list of ethnic groups and systematically identified their access to state power through an expert survey (see Cederman, Wimmer \& Min, 2010). In a pioneering early dyadic analysis of ethnic civil war, Buhaug, Cederman \& Rød (2008) examined the relative influence of motivation - based on whether ethnic groups are political excluded - and opportunities, given the size of a group relative to the 'included' groups dominating a state. Previous research had found that measures of ethnic diversity such as fractionalization did not appear strongly related to the outbreak of civil and largely dismissed the role of ethnicity (see, e.g., Collier \& Hoefller, 2004; Fearon \& Laitin, 2003). However, indices of ethnic fractionalization or diversity do not reflect grievances and 
opportunities at the group level (as highlighted by the MAR project), nor political status or the relationship of a group to the state, as emphasized in the EPR project. The state is rarely a neutral actor, and the more relevant feature for conflict is not ethnic diversity but whether individual groups are actively excluded by the state. Buhaug et al. (2008) find strong evidence that ethnic political exclusion can dramatically increase the risk of civil war, especially when groups have more resources to confront the state militarily. Whereas early research looking at interpersonal income inequality found little evidence of a relationship to conflict, research looking at inequality rates across ethnic groups, using either survey data or GIS data on economic activity and ethnic settlements, find much stronger support for a relationship between grievances in the economic domain and conflict (see Cederman, Weidmann \& Gleditsch, 2011; Østby, 2008). In this sense, a critical reexamination of the relationship between the underlying theories and measures in past research has helped develop more precise theoretical arguments and greater awareness of what is needed for appropriate data for empirical tests.

\section{Disaggregation III: Strategies and tactics in conflict}

Our first two cases of disaggregation pertained to 'when/where' or 'who' fights in conflict. A third form of disaggregation in conflict studies looks explicitly at 'how' actors interact with one another. With the exception of some studies using event data, traditional conflict studies have tended to use deaths solely to identify 'conflicts', and generally paid less attention to who gets killed and the specific tactics and strategies actors use. For example, recent research has looked at when parties to conflict intentionally target civilians, either as substitutes to attacking opponents directly or to complements such activities. Valentino et al. (2004) argue that 
governments often turn to target the civilian support base when they are unable to defeat insurgencies in the periphery. In a JPR article, Eck \& Hultman (2007) develop new data on Onesided Violence (OSV) during domestic conflicts, including killing of civilians perpetrated both by governments and rebels. Their results indicate that civilians by no means are universally attacked during civil war, and suggest that both governments and rebels often have incentives to exercise restraint and normally face significant risks from carrying out actions that are likely to alienate civilians. Governments are more likely to kill in larger numbers when they systematically target civilians, but rebels are generally more likely to target civilians than governments. Wood (2010) argues that weak rebels target civilians when they lack the ability to generate support through selective benefits and find themselves forced to rely on coercion.

Beyond direct or intentional targeting, other studies have started to examine indirect forms of targeting such as terrorism, where actors may attack more or less random individual targets to 'terrorize' or communicate with a specific target audience (see, e.g., Balcells, 2011; Sandler, 2011). For example, if an organization carries out a surprise bomb attack on civilians in city to generate a significant crisis for the government, the location or identity of the resulting victims may be essentially irrelevant. Findley \& Young (2012) examine the relationship between civil war and terrorist attacks, and find that terrorism appears to be a relatively common tool in civil war, in spite of the common focus on conventional strategies and battledeaths as a defining characteristic of civil war and the notion that terrorism is a 'weapon of the weak', presumably unable to engage in conventional conflict.

Recent research has distinguished specific organizations on the rebel side, but often assumed the state to be a cohesive actor. In a recent JPR article, Carey et al. (2013) emphasize how governments often delegate violence to more or less autonomous agents, and present a new 
data base on pro-government militias. Governments may delegate or rely on autonomous militias when these can project force more effectively than the conventional security apparatus, or provide opportunities for denying responsibility for atrocities.

Although the study of patterns of targeting and killing in conflict is a relatively new research area, there are in our view already many interesting results. For example, this research suggests possible limiting factors that can help account for why civil wars do not escalate in battledeath severity at the same rate as interstate wars. The latter are known to follow a so-called power law distribution, where frequency is inversely proportional to severity (see Cederman, 2003). By contrast, civil wars have 'too few' severe observations to fit such distributions (see Clauset et al., 2012). Since rebel forces tend to be small and weaker than governments, civil wars are unlikely to see large numbers of battledeaths to the same extent as interstate wars, where both parties have fewer resource constraints. If governments turn to targeting civilians rather than combatants we see genocides rather than conventional battledeaths. Alternatively, civil wars that escalate may be more likely to draw in other states and become interstate wars. In this respect, it is instructive that many major conflicts such as World War I and the Peloponnesian War initially were triggered by intrastate conflict events.

A tactical perspective on civil wars can also help us understand conflict dynamics and different exit options, such as when parties seek negotiations or settlements and when these are likely to remain stable. For example, Metternich (2011) argues that the willingness of rebels to accept a conflict settlement involving democratization depends on how well they expect to do in competitive elections. Findley \& Young (2012) find evidence that terrorist attacks occur after civil wars, consistent with a motivation to 'spoil' peace processes (e.g., Stedman, 1997). Other research examining the relationship between terrorist attacks and elections indicates that terrorist 
groups can both have incentives to carry out attacks before elections to demonstrate that they are a force to be reckoned with as well as to prevent attacks before elections to show that they have the ability to control violence if the government is open to negotiations (see Clauset et al., 2010).

Strategic conflict behavior highlights the important distinction between features that may not be covered in existing data, but are known or observable ex ante by the actors in conflict and in principle could be collected, and features that are imperfectly known ex ante by the actors and difficult to evaluate consistently even ex post. Observed strategic behavior is usually assumed to be based - at least partially - on unobservable characteristics. Much of the important variation in types of actors - such as their resolve - and private information such as strategies, cost, and reservation point are often inherently and deliberately hidden and unobservable. Data collection efforts will have a very hard time to identify and measure such characteristics, and ex post assessments might potentially reflect features only know after the events rather than the ex ante beliefs of the actors. However, theory may be able to guide our research, and strategic theories typically will often have observable implications that we can consider in terms of sequencing, for example, inferring types by whether one actor A choses one alternative over another following some action by its antagonist $\mathrm{B}$.

\section{Disaggregation IV: Conflict beyond violence}

Most research so far has been limited to conflict as episodes of violence reaching some battle death threshold, save for some studies using event data (e.g. Bond et al., 2003). There is an increasing recognition that studying only violent conflict may be too limiting to understand conflict process and the possible factors that can lead actors to the use as well as explicit 
abstention from violence. Stated differently, if the first three forms of disaggregation can be summarized as the need to know 'when/where', 'who', and 'what', if we wish to understand how such grievances may motivate violence we also need to be able to account for 'what else', or when parties may pursue alternative strategies or chose not to use violence.

Some researchers have pointed to how insurgencies require considerable organization, and that mobilization often precedes the use of violence considerably (see, e.g., Regan \& Norton, 2005). Rather than studying violence as appearing out of nowhere, researchers should study the preceding interactions between dissidents and governments (see, e.g., Lichbach, 1987; Moore, 1998). At a more fundamental level, most conceptual definitions of conflict stress incompatibilities between actors as the defining characteristics. Although these may give rise to incentives to use violence, incompatibilities can also be managed in different ways without the use of force, and actors may chose a variety of different ways to respond to their opponents (e.g., Boulding, 1963; Fearon, 1995). For example, many researchers have examined the use of nonviolent tactics to topple autocratic regimes or to secede from a state or imposed rule (Chenoweth \& Stephan, 2011; Nepstad, 2011; Sharp, 1973). These can clearly be seen as cases where nonstate actors have grievances over the government or seek autonomy over specific territories (in line with UCDP incompatibilities), yet for various reasons chose to pursue their objectives through non-violent actions rather than violence. The so-called Arab Spring in particular has led to a resurgence of interest in non-violent conflict and tactics. ${ }^{7}$

\footnotetext{
${ }^{7}$ Non-violent direct action is classified exclusively based on the behavior of non-state actors, and the government side often uses violence or repressive means. Moreover, governments may also repress individuals in the absence of manifest conflict, possibly to prevent threats or collective
} 
Research on non-violence has often been dominated by normative or activism oriented contributions and remained largely peripheral to the social sciences (see, e.g., Shock 2004). However, JPR has always published material on the relationship between violence and nonviolent direct action. Much of this has tended to be conceptual or case-based studies rather than based on systematic comparative data (see, e.g., Galtung 1965; Martin 1989; Martin \& Varney 2003). An important early exception is Bond (1986), who generated a typology of non-violent direct action from factor analysis of event data. There is an important conceptual distinction between routine politics, or actions that are in accordance with prevailing rules, such as voting or petitions in democratic systems, and direct action in contravention of existing rules, where actors either do something that the state wishes to prevent or refuse to do something the state orders them to do (see Bond, 1994). The so-called Non-violent and Violent Campaign Data (NAVCO) developed by Chenoweth \& Stepan (2011) have led to a surge in empirical studies of non-violent conflict, and in particular under what conditions violent versus non-violent campaigns are likely to be more successful. Chenoweth \& Stepan (2011) find that non-violent campaigns tend to be more likely to achieve their objective than violent campaigns. Svensson \& Lindgren (2011) find that non-violent campaigns over territorial incompatibilities have faced much greater difficulties than campaigns contesting the government, which may reflect more fundamental differences the groups and resources for actors in urban and rural conflicts. Although the original NAVCO 1.0 data were available only as aggregate spells, indicating largely violent and non-violent overall campaigns over some contentious issue, the new 2.0 version outlined in Chenoweth \& Orion

action in the first place. More detailed data on government repression can help in studying reactive and preemptive responses to dissent and how this influences dissident motives and strategies (see e.g., Conrad et al., 2013). 
(2013) provide annual information on activities within campaigns, and the project will eventually be extended to collect event data for particular campaigns in a third phase.

\section{Advancing peace research: The future of conflict data}

Many surveys of scientific approaches to the study of conflict and peace have reached very pessimistic conclusions, often lamenting the lack of accumulation (see, e.g., Bennett \& Stam, 2003). Jervis (1976) went so far as to characterize the subfield as chasing 'woozles' - the imaginary creatures popularized in Winnie the Pooh - or results that simply are not there. We strongly disagree with this assessment, and we think our review here on the contrary demonstrates the great amount of learning that has taken place, especially over recent years. Learning and progress in any field requires theoretical foundations. Greater data availability has on the one hand done much to facilitate empirical testing of existing propositions. At the same time it has also helped us develop new research questions and stronger theoretical foundations for the broader field of conflict research. Steps toward disaggregating data on conflict in space and time (i.e., 'where' and 'when' questions) have in turn helped foster greater attention to the role of agency (i.e., questions about 'who' fights in conflict, their motivations, relative capacity and constraints) as well as the possible choice of strategies (i.e., questions about 'how' actors pursue their objectives in interactions over incompatibilities). Although much of the empirical study of conflict (if not conceptual work) has been limited to violent conflict, we see recent extensions and data projects that allow studying 'what else' or strategies in conflict, including non-violent direct action that have often been neglected in many theories of conflict (e.g. Chenoweth \& Stephan, 2011, Salehyan et al., 2012). Even if empirical research has a tendency to 
look under the proverbial lamppost, or select research projects on the basis of data availability, the dramatic expansion in conflict data ensures that the area under the lamppost has expanded, thereby also broadening our theoretical horizons.

Our emphasis on disaggregation here might give the impression that disaggregation is a goal in itself and that more disaggregation is always inherently better. We stress that the appropriate level of aggregation depends on the specific research question (see Cederman \& Gleditsch, 2009), which in turn of course must depend on theory. In some cases, more aggregation of individual data observations may actually be the most appropriate and useful, in particular when examining long-run trends and patterns, as in recent work on the global decline of conflict and violence (see, e.g., Goldstein, 2011; Lacina et al., 2006; Pinker, 2011). However, data are not necessarily tied to specific research questions or any single level of analysis or measures. For example, in many cases it may often be possible to construct more theoretically informative measures at a higher level of aggregation such as countries by scaling up information at lower level observations such as geographical grid cells or satellite image data, focusing on features such as weakest link (i.e., $\max / \mathrm{min}$ ) rather than the average (see Gleditsch \& Weidmann, 2012). In addition, we should expect theoretical precision appropriate for the data and be vary of efforts to simply extend existing theories uncritically to new and more detailed data. Some general theoretical mechanisms and approaches have empirical implications across many levels of aggregation (e.g., bargaining, collective action, or principal agent theories), and many propositions on the onset of conflict can fruitfully be examined on more fine detailed data, reflecting important local variation. In other cases, however, we may need much more context specific theories, in particular with regards to accounting for dynamics in conflicts or 
escalation/de-escalation processes across geographical units, which are unlikely to be well addressed by propositions developed for the outbreak of conflict.

Theory aside, the development of disaggregated conflict data highlights many important and enduring challenges, including the quality of the underlying sources. Traditional conflict data have been coded based on historical narratives and sources. These often provide a wealth of information, but rarely use explicit and comparable methodologies. Moreover, the interpretations and conclusions presented in one source can often be contentious and not accepted by other scholars (see, e.g., Goldthorpe, 1991). This is obviously also the case for features such as battledeaths, intentional, or preventable deaths. For example, different sources report divergent casualties figures for the ongoing military conflict in Syria (see Price et al., 2013). Common practices such as averaging sources or taking a consensus estimate may be problematic if individual sources display common biases (see, e.g., Davenport, 2010). Conflict data can benefit from greater transparency as well as more attention to source criticism. For a specific example from JPR, see Dulic's (2004) critical discussion of Rummel's (1995) democide data for Yugoslavia and Rummel's (2004) reply. Jerven (2013) highlights how the existence of multiple data sources on conflict and debates about their relative merits have helped foster greater transparency, and how conflict data compare favorably to macroeconomic data for developing countries that often lack transparency on the underlying sources and specific methodologies. Still, many data projects could benefit from more explicit documentation of sources and decisions.

Big data raises questions about the potential trade-offs between quality, quantity, and costs. Human coders can be costly or impractical in large projects (Schrodt, 2012). Computer automated approaches can minimize human errors, and outsourcing through web-based 
platforms can be cost effective if the decreased efficiency of non-expert coders can be compensated for by greater numbers of coders at a lower price. Still, expert coding may have a place for particular more difficult tasks where automated coding fails or non-experts do not converge on the correct value, or possibly do not understand the underlying concepts (see Ruggeri, Gizelis \& Dorussen, 2011).

More data aside, many significant problems arise in statistical analyses of disaggregated conflict data. There is often an overemphasis on statistical significance tests and fitting more complex model in-sample over substantive interpretation and out-of-sample prediction (see Schrodt 2013; Ward, Greenhill \& Bakke, 2010). More disaggregated data raise additional challenges with regards to spatial and temporal dependence. A larger $\mathrm{N}$ in more disaggregated data does not always entail a corresponding increase in the effective number of independent observations, and researchers should be hesitant to apply standard interpolation methods assuming smooth variation across continuous fields unless these can be justified explicitly (see Gleditsch \& Weidmann, 2012). Moreover, disaggregation does not by itself address issues such as possible endogenous relationships and problems of causal inference. However, more detailed data allow enables researchers to better establish sequences and often allow implement more sophisticated research designs. For example, recent conflict research has used designs such as natural experiments, matching techniques, difference-in-differences estimation, spatial analyses, and time-series approaches in ways that have drawn the attention of scholars outside the field.

The future of conflict data will certainly involve 'big' and disaggregated data, blurring the line between qualitative and quantitative research, with new opportunities for theoretical and empirical innovation. In our view, data and theory must be seen as a couple, like Sherlock Holmes and Dr. Watson, where the relationship itself is fundamental and the interaction leads to 
something distinctly more than the sum of the parts. The interaction of theory and data has in our view helped bring about scientific progress in the first 50 years of JPR. This is an achievement that clearly calls for a celebration, and we are confident that the journal will continue to play a similar role in the future. 


\section{References}

Azar, Edward E (1980) The conflict and peace databank (COPDAB) project. Journal of Conflict Resolution 24 (1):143-152.

Bennett, D Scott \& Allan C Stam (2003) The Behavioral Origins of War. Ann Arbor, MI: University of Michigan.

Balcells, Laia (2011) Continuation of politics by two means: Direct and indirect violence in civil war. Journal of Conflict Resolution 55 (3):397-422.

Bond, Douglas G (1986) The nature and meanings of nonviolent direct action: An exploratory study. Journal of Peace Research 25 (1):81-89.

Bond, Douglas G (1994) Nonviolent Direct Action and the Diffusion of Power. In: Paul Wehr, Heidi Burgess \& Guy Burgess (eds.) Justice Without Violence. Boulder, CO: Lynne Rienner.

Blattman, Christopher (2009) From violence to voting: War and political participation in Uganda. American Political Science Review 103 (2):231-247.

Blattman, Christopher \& Edward Miguel (2010) Civil war. Journal of Economic Literature 48 (1):3-57.

Boulding, Kenneth E (1963) Conflict and Defense: A General Theory. New York: Harper and Row. 
Braithwaite, Alex (2010) MIDLOC: Introducing the militarized interstate dispute location dataset. Journal of Peace Research 47 (1):91-98.

Brecher, Michael \& Jonathan Wilkenfeld (1982) Crisis in world politics. World Politics 34 (3):380-417.

Brecke, Peter (1999/2012) Violent conflicts 1400 A.D. to the present in different regions of the world. Paper presented at the annual meeting of the Peace Science Society, 8-10 October; 2012 version of the data available at http://www.cgeh.nl/institutions-hub.

Buhaug, Halvard; Lars-Erik Cederman \& Jan Ketil Rød (2008) Disaggregating ethno-nationalist civil wars: A dyadic test of exclusion theory. International Organization 62 (3):531-551.

Buhaug, Halvard \& Scott Gates (2002) The geography of civil war. Journal of Peace Research 39 (4):417-33.

Carey, Sabine; Neil Mitchell \& Will Lowe (2013) States, the security sector and the monopoly of violence: A new database on pro-government militias. Journal of Peace Research 50 (2):249-258.

Cederman, Lars-Erik (2003) Modeling the size of wars: From billiard balls to sandpiles. American Political Science Review 97 (1):135-150.

Cederman, Lars-Erik, Andreas Wimmer \& Brian Min. 2010. Why do ethnic groups rebel? New data and analysis. World Politics 62 (1):87-119.

Cederman, Lars-Erik, Nils B Weidmann \& Kristian Skrede Gleditsch (2011) Horizontal inequalities and ethnonationalist civil war: A global comparison. American Political Science Review 105 (3):478-495. 
Cederman, Lars-Erik \& Kristian Skrede Gleditsch (2009) Special issue on 'Disaggregating civil war'. Journal of Conflict Resolution 53 (4):487-495.

Chenoweth, Erica \& Maria J Stephan (2011) Why Civil Resistance Works: The Strategic Logic of Nonviolent Conflict. New York, NY: Columbia University Press.

Chiozza, Giacomo \& Henk E Goemans (2004a) International conflict and the tenure of leaders: Is war still ex post inefficient? American Journal of Political Science 48 (3):604-619.

Chiozza, Giacomo \& Henk E Goemans (2004b) Avoiding diversionary targets. Journal of Peace Research 41 (4):423-443.

Clauset, Aaron, Lars-Erik Cederman \& Kristian Skrede Gleditsch (2012) The distribution and dynamics of war sizes. Paper presented to the German Physics Society, focus session on 'Models of war and conflict', Berlin, 25-30 March.

Clauset, Aaron, Lindsay Heger, Maxwell Young \& Kristian Skrede Gleditsch (2010) The strategic calculus of terrorism: Substitution and competition in the Israel-Palestine conflict. Cooperation and Conflict 45 (1):6-33.

Collier, Paul, Anke Hoeffler \& Dominic Rohner (2009) Beyond greed and grievance: Feasibility and civil war. Oxford Economic Papers 61 (1):1-27.

Conrad, Courtenay R; Jillienne Haglund \& Will H Moore (2013) Disaggregating torture allegations: Introducing the ill-treatment and torture (ITT) country-year data. International Studies Perspectives 14 (2):199-220. 
Cunningham, David E, Kristian Skrede Gleditsch \& Idean Salehyan (2009) It takes two: A dyadic analysis of civil war duration and outcome. Journal of Conflict Resolution 53 (4):570-597.

Deutsch, Karl W (1970) Quincy Wright's contribution to the study of war. Journal of Conflict Resolution 14 (4):473-478.

DeRouen, Karl and Jacob Bercovitch \& Paulina Pospieszna (2011) Introducing the civil wars mediation (CWM) dataset. Journal of Peace Research 48 (5):663-672.

Dulić, Tomislav (2004) Tito's slaughterhouse: A critical Analysis of Rummel's work on democide. Journal of Peace Research 41 (1):85-102.

Eck, Kristine \& Lisa Hultman (2007) One-sided violence against civilians in war: Insights from new fatality data. Journal of Peace Research 44 (2):233-246.

Fearon, James D \& David D Laitin (2003) Ethnicity, insurgency, and civil war. American Political Science Review 97 (1):75-90.

Fjelde, Hanne (2010) Generals, dictators and kings: Authoritarian regimes and civil conflict, 1973-2004. Conflict Management and Peace Science 27 (3):195-218.

Galtung, Johan (1965) Institutionalized conflict resolution: A theoretical paradigm. Journal of Peace Research 2 (4):348-397.

Gat, Azar (2008) War in Human Civilization. Oxford: Oxford University Press.

Gleditsch, Kristian Skrede (2002) All International Politics is Local: The Diffusion of Conflict, Integration, and Democratization. Ann Arbor, MI: University of Michigan Press. 
Gleditsch, Kristian Skrede (2004) A revised list of wars between and within independent states, 1816-2002. International Interactions 30 (4):231-262.

Gleditsch, Kristian Skrede \& Steve Pickering (forthcoming) Wars are becoming less frequent: A reply to Harrison and Wolf. Economic History Review, in press.

Gleditsch, Kristian Skrede, Idean Salehyan \& Kenneth Schultz (2008) Fighting at home, fighting abroad: How civil wars lead to interstate disputes. Journal of Conflict Resolution 52 (4):479-506.

Gochman, Charles S. \& Zeev Maoz (1984) Militarized interstate disputes, 1816-1976: Procedures, patterns, and insights. Journal of Conflict Resolution 28 (4):585-616.

Goemans, Henk E, Kristian Skrede Gleditsch \& Giacomo Chiozza (2009) Introducing Archigos: A dataset of political leaders. Journal of Peace Research 46 (2): 269-283.

Goldthorpe, John H (1991) The uses of history in sociology: Reflections on some recent tendencies. British Journal of Sociology 42 (2):211-230.

Goldstein, Joshua S (2011) Winning the War on War: The Decline of Armed Conflict Worldwide. Hialeah, FI: Dutton/Penguin.

Ghosn, Faten, Glenn Palmer \& Stuart Bremer (2004) The MID3 data set, 1993-2001: Procedures, coding rules, and description. Conflict Management and Peace Science 21 (2):133-154.

Gurr, Ted Robert (1993) Minorities at Risk: A Global View of Ethnopolitical Conflict. Washington, DC: United States Institute of Peace Press. 
Hallberg, Johan Dittrich (2012) PRIO conflict site 1989-2008: A geo-referenced dataset on armed conflict. Conflict Management and Peace Science 29 (2):219-232.

Harbom, Lotta; Erik Melander \& Peter Wallensteen (2008) Dyadic dimensions of armed conflict, 1946-2007. Journal of Peace Research 45 (5):697-719.

Harrison, Mark \& Nikolaus Wolf (2012) The frequency of wars. Economic History Review 65 (3):1055-1076.

Hermann, Margaret, ed. (1977) A Psychological Examination of Political Leaders. New York: Free Press.

Hermann, Margaret G (1980) Explaining foreign policy behavior using the personal characteristics of political leaders. International Studies Quarterly 24 (1):7-46.

Jaggers, Keith \& Ted R Gurr (1995) Tracking democracy's third wave with the Polity III data. Journal of Peace Research 32 (4):469-482.

Jerven, Morten (2013) Poor Numbers: How We are Misled by African Development Statistics and What to Do About it. Ithaca, NY: Cornell University Press.

Jervis, Robert (1976) Cumulation, Correlation, Woozles. In: James N. Rosenau (ed.) In Search Global Patterns. New York: Free Press.

Jones, Daniel M, Stuart A Bremer \& J David Singer (1996) Militarized interstate disputes, 18161992: Rationale, coding rules, and empirical applications. Conflict Management and Peace Science 15 (2):163-213. 
King, Gary, Robert O Keohane \& Sidney Verba (1994) Designing Social Inquiry: Scientific Inference in Qualitative Research. Princeton, NJ: Princeton University Press.

King, Gary \& Will Lowe (2003) An automated information extraction tool for international conflict data with performance as good as human coders: A rare events evaluation design. International Organization 57 (3):617-642.

Kreutz, Joakim (2010) How and when armed conflicts end: Introducing the UCDP conflict termination dataset. Journal of Peace Research 47 (2):243-250.

Leetaru, Kalev \& Philip A Schrodt (2013) GDELT: Global data on events, location, and tone, 1979-2012. Presented at the annual meeting of the International Studies Association, San Francisco, CA, 3-6 April.

Levy, Jack (1983) War in the Modern Great Power System, 1495-1975. Lexington, KY: University of Kentucky Press.

Lieberson, Stanley (1992) Einstein, Renoir, and Greeley: Some thoughts about evidence in sociology. American Sociological Review 57 (1): 1-15.

Lyall, Jason (2010) Are coethnics more effective counterinsurgents? Evidence from the second Chechen war. American Political Science Review 104 (1):1-20.

Martin, Brian (1989. Gene Sharp's theory of power. Journal of Peace Research 26 (2):213-222.

Martin, Brian \& Wendy Varney (2003) Nonviolence and communication. Journal of Peace Research 40 (2):213-232. 
McClelland, Charles A (1983) Let the user beware. International Studies Quarterly 27 (2):169177.

McGowan, Pat; Harvey Starr, Gretchen Hower, Richard Merritt \& Dina Zinnes (1988) International data as a national resource. International Interactions 14 (2): 101-13

Metternich, Nils W (2011) Expecting elections: Interventions, ethnic support, and the duration of civil wars. Journal of Conflict Resolution 55 (6):909-937.

Metternich, Nils W; Cassy Dorff, Max Gallop, Simon Weschle \& Michael D Ward (2013) Antigovernment networks in civil conflicts: How network structures affect conflictual behavior. American Journal of Political Science, forthcoming.

Morrow, James D (2000) The Ongoing Game-Theoretic Revolution. In: Manus I. Midlarsky (ed.) Handbook of War Studies II. Ann Arbor, MI: University of Michigan Press.

Nepstad, Sharon Erickson (2011) Nonviolent Revolutions: Civil Resistance in the Late 20th Century. Oxford: Oxford University Press.

Østby, Gudrun (2008) Polarization, horizontal inequalities and violent civil conflict. Journal of Peace Research 45 (2):143-162.

Oneal, John R, Frances Oneal, Zeev Maoz \& Bruce M Russett (1996) The liberal peace: Democracy, interdependence, and conflict, 1950-1985. Journal of Peace Research 33 (1):11-28

Payne, James L (2004) A History of Force: Exploring the Worldwide Movement Against Habits of Coercion, Bloodshed, and Mayhem. Sandpoint, IN: Lytton. 
Price, Megan; Jeff Klingner \& Patrick Ball (2013) Preliminary statistical analysis of documentation of killings in the Syrian Arab Republic. Reported commissioned by the United Nations Office of the High Commissioner for Human Rights.

Pinker, Steven (2011) The Better Angels of Our Nature: Why Violence has Declined. New York: Viking.

Pool, Ithiel de Sola (1965) The Kaiser, the Tsar, and the computer: Information processing in a crisis. American Behavioral Scientist 8 (9):31-39.

Raleigh, Clionadh; Andrew Linke, Håvard Hegre \& Joakim Karlsen (2010) Introducing ACLED: An armed conflict location and event dataset. Journal of Peace Research 47 (5):651-660.

Restrepo, Jorge A, Michael Spagat \& Juan F Vargas (2006) The severity of the Colombian conflict: Cross-country datasets versus new micro-data. Journal of Peace Research 43 (1):99-115.

Richardson, Lewis F (1960a) Statistics of Deadly Quarrels. Chicago, Pittsburgh, PA: Quadrangle/Boxwood.

Richardson, Lewis F (1960b) Arms and Insecurity. Chicago, Pittsburgh, PA: Quadrangle/Boxwood.

Richardson, Lewis F (1948) Variation of the frequency of fatal quarrels with magnitude. Journal of the American Statistical Association 43 (244):523-546.

Ruggeri, Andrea; Theodora-Ismene Gizelis \& Han Dorussen (2011) Events data as Bismarck's sausages? Intercoder reliability, coders' selection, and data quality. International Interactions 37(1):340-361 
Rummel, Rudolph J (1985) Libertarian propositions on violence within and between nations. Journal of Conflict Resolution 29 (3):419-455.

Rummel, Rudolph J (1995) Death by Government. New Brunswick, NJ: Transaction Publishers.

Rummel, Rudolph J (2004) One-thirteenth of a data point does not a generalization make: A response to Dulić. Journal of Peace Research 41(1):103-104.

Salehyan, Idean (2010) The delegation of war to rebel organizations. Journal of Conflict Resolution 54 (3):493-515.

Salehyan, Idean; Cullen S Hendrix, Christina Case, Christopher Linebarger, Emily Stull \& Jennifer Williams (2012) The social conflict in Africa database: New data and applications. International Interactions 38(4):503-511.

Salehyan, Idean (2009) Rebels Without Borders: State Boundaries, Transnational Opposition, and Civil Conflict. Ithaca, NY: Cornell University Press.

Sandler, Todd (2011) New frontiers of terrorism research. Journal of Peace Research 48 (3):279-286.

Schock, Kurt (2005) Unarmed Insurrections: People Power Movements in Nondemocracies. Minneapolis, MN: University of Minnesota Press.

Schrodt, Philip (2013) Seven deadly sins of contemporary quantitative political analysis. Journal of Peace Research, forthcoming.

Schrodt, Philip (2012) Precedents, progress, and prospects in political event data. International Interactions 38 (4):546-569 
Sharp, Gene (1973) The Politics of Nonviolent Action. Boston, MA: Porter Sargent.

Singer, J David, ed. (1980) The Correlates of War II: Testing Some Realpolitik Models. New York: Free Press.

Singer, J David, Stuart Bremer \& John Stuckey (1972) Capability Distribution, Uncertainty, and Major Power War. In: Bruce M Russett (ed.) Peace, War, and Numbers. Beverly Hills, CA: Sage.

Small, Melvin \& J David Singer (1982) Resort to Arms: International and Civil Wars, 18161980. Beverly Hills, CA: Sage.

Stedman, Stephen John (1997) Spoiler problems in peace processes. International Security 22 (2):5-53.

Sorokin, Pitirim A (1957) Social and Cultural Dynamics. London: Owen.

Valentino, Benjamin; Paul Huth \& Dylan Balch-Lindsay (2004) 'Draining the sea': Mass killing and guerrilla warfare. International Organization 58 (2):375-407.

Verwimp Philip, Patricia Justino \& Tilman Brück (2009) The analysis of conflict: A micro-level perspective. Journal of Peace Research 46 (3): 307-314.

Ward, Michael D, Brian D Greenhill \& Kristin M Bakke (2010) The perils of policy by p-value: Predicting civil conflict. Journal of Peace Research 45 (5): 363-375.

Wallensteen, Peter \& Karen Axell (1993) Armed conflict at the end of the conflict war, 19891992. Journal of Peace Research 30 (3):331-346. 
Weeks, Jessica L (2012) Strongmen and straw men: Authoritarian regimes and the initiation of international conflict. American Political Science Review 106 (2):326-347.

Weidmann, Nils B (2011) Violence 'from above' or 'from below'? The role of ethnicity in Bosnia's civil war. Journal of Politics 73 (4):1178-1190.

Wilkenfeld, Jonathan (1968) Domestic and foreign conflict behavior of nations. Journal of Peace Research 5 (1):56-69.

Wimmer, Andreas (2002) Nationalist Exclusion and Ethnic Conflicts: Shadows of Modernity. Cambridge: Cambridge University Press.

Wood, Reed (2010) Rebel capability and strategic violence against civilians. Journal of Peace Research 47 (5):601-614.

Wright, Quincy (1942/1965) A Study of War. Chicago: University of Chicago Press. 


\section{Biographical statements}

KRISTIAN SKREDE GLEDITSCH, b. 1971, PhD in Political Science (University of Colorado,

Boulder, 1999); Professor, Department of Government, University of Essex (2005- ); Research Associate, Peace Research Institute Oslo (2003- ). Author of Inequality, Grievances, and Civil

War (with Halvard Buhaug and Lars-Erik Cederman, Cambridge University Press, 2013), All

International Politics is Local: The Diffusion of Conflict, Integration, and Democratization (University of Michigan Press, 2002) and recent articles in American Political Science Review, International Organization, Journal of Conflict Resolution, and World Politics.

NILS W. METTERNICH, b. 1979, PhD in Government (University of Essex, 2011); Lecturer, Department of Political Science, University College London (2013- ). Recent articles have appeared in American Journal of Political Science, Journal of Conflict Resolution, and World Politics.

ANDREA RUGGERI, b. 1982, PhD in International Relations (University of Essex, 2011); Assistant Professor, Department of Political Science, University of Amsterdam (2010- ). Recent articles have appeared in Journal of Conflict Resolution, Journal of Peace Research, and International Interactions. 